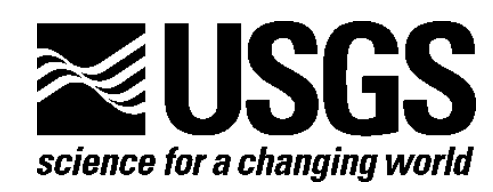

\title{
Soil Physical, Chemical, and Gas-Flux Characterization from Picea mariana Stands near Erickson Creek, Alaska
}

By Jonathan A. O'Donnell, Jennifer W. Harden, and Kristen L. Manies

Open-File Report 2011-1153

U.S. Department of the Interior U.S. Geological Survey 


\section{U.S. Department of the Interior \\ KEN SALAZAR, Secretary}

\section{U.S. Geological Survey \\ Marcia K. McNutt, Director}

U.S. Geological Survey, Reston, Virginia: 2011

For product and ordering information:

World Wide Web: http://www.usgs.gov/pubprod

Telephone: 1-888-ASK-USGS

For more information on the USGS—-the Federal source for science about the Earth, its natural and living resources, natural hazards, and the environment:

World Wide Web: http://www.usgs.gov

Telephone: 1-888-ASK-USGS 


\section{Contents}

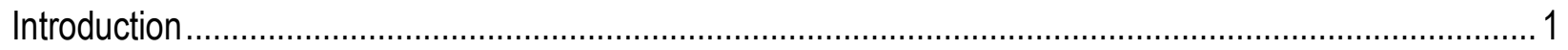

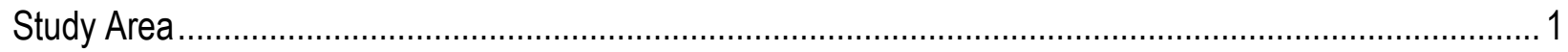

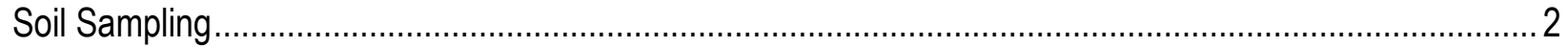

Soil-Sample Preparation and Drying.............................................................................................. 3

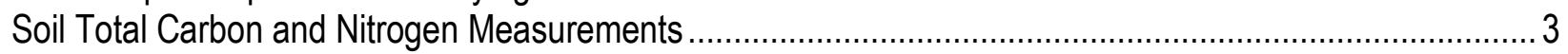

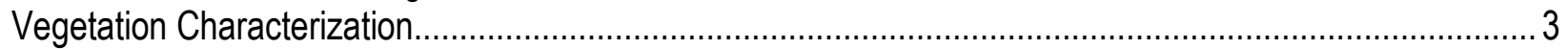

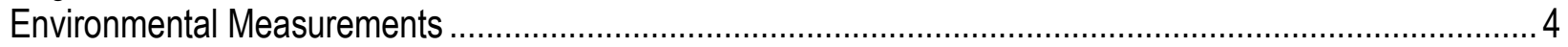

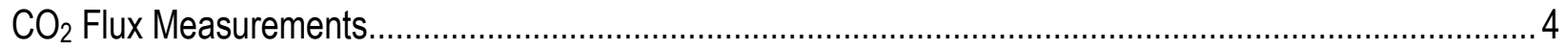

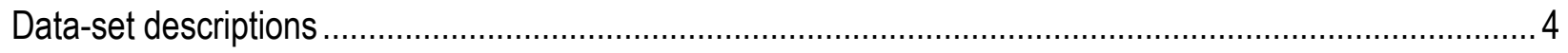

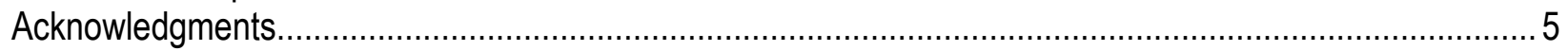

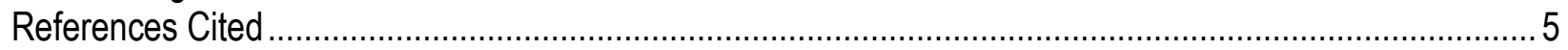

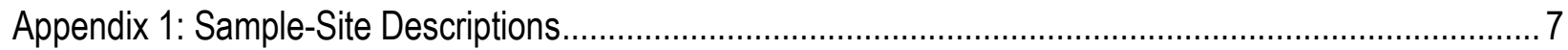

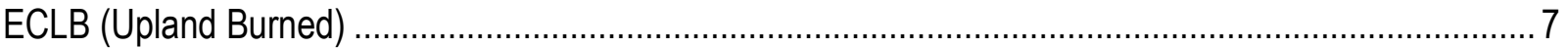

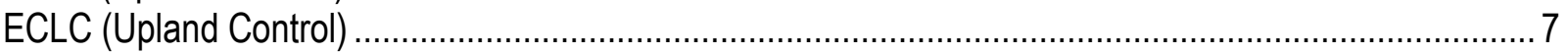

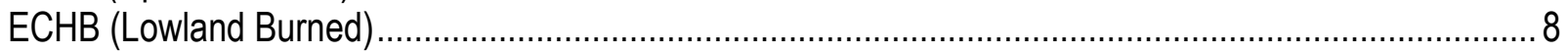

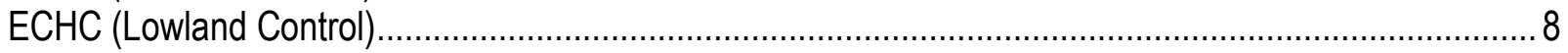

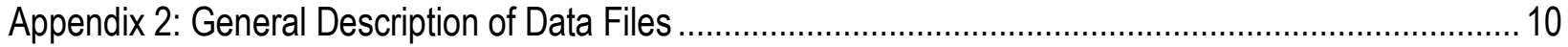

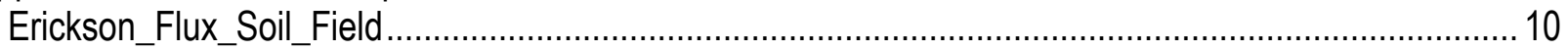

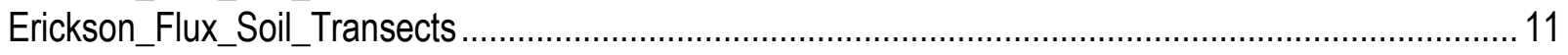

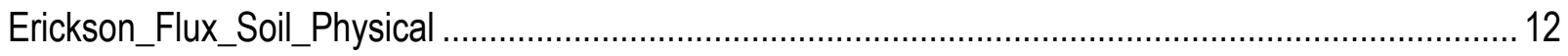

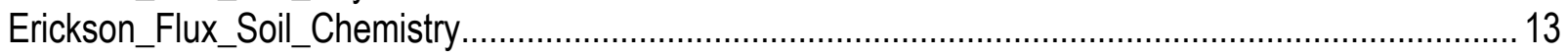

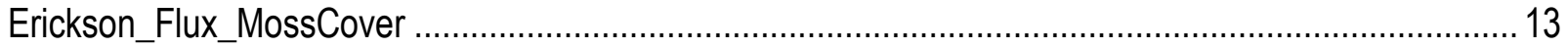

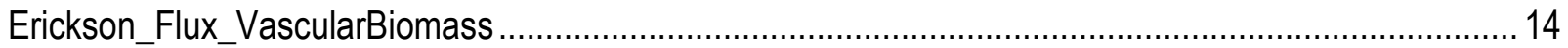

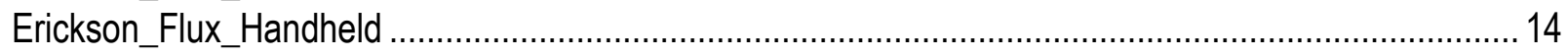

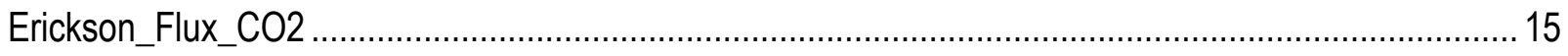




\title{
Soil Physical, Chemical, and Gas-Flux Characterization from Picea mariana Stands near Erickson Creek, Alaska
}

\author{
By Jonathan A. O’Donnell, Jennifer W. Harden, Kristen L. Manies
}

\section{Introduction}

Fire is a particularly important control on the carbon $(\mathrm{C})$ balance of the boreal forest (Kasischke and others, 1995, 2000; Harden and others, 2000), and fire-return intervals and fire severity appear to have increased since the late 1900s in North America (Kasischke and Turetsky, 2006). In addition to the immediate release of stored $\mathrm{C}$ to the atmosphere through organic-matter combustion, fire also modifies soil conditions, possibly affecting $C$ exchange between terrestrial and atmospheric pools for decades after the burn (Richter and others, 2000; O’Neill and others, 2002, 2003). The effects of fire on ecosystem $\mathrm{C}$ dynamics vary across the landscape, with topographic position and soil drainage functioning as important controls (Kane and others, 2007).

The data reported here contributed to a larger U.S. Geological Survey (USGS) study, published in the journal Ecosystems by O'Donnell and others (2009). To evaluate the effects of fire and drainage on ecosystem $\mathrm{C}$ dynamics, we selected sample sites within the 2003 Erickson Creek fire scar to measure $\mathrm{CO}_{2}$ fluxes and soil $\mathrm{C}$ inventories in burned and unburned (control) sites in both upland and lowland black spruce (Picea mariana) forests. The results of this study suggested that although fire can create soil climate conditions which are more conducive to rapid decomposition, rates of $\mathrm{C}$ release from soils may be constrained after fire by changes in moisture and (or) substrate quality that impede rates of decomposition (O’Donnell and others, 2009). Here, we report detailed site information, methodology, and data (in spreadsheet files) from that study.

\section{Study Area}

Sample sites were located within the 2003 Erickson Creek fire scar, just north of Livengood, Alaska. Using aerial photography, we selected unburned sites adjacent to the fire scar in both upland and lowland black spruce. Unburned (control) sites were similar in slope, aspect, and ground-layer and canopy characteristics relative to burned sites. All sites were underlain by permafrost; depths of the active layer (i.e. the region of soil above the permafrost table that thaws and refreezes every year) ranged from 40 to $60 \mathrm{~cm}$. Appendix 1, Erickson_Flux_Site_Descriptions, describes the location of each sample site and precisely where, within each site, soils were sampled.

All samples were labeled with a code describing the site and location from which the samples were obtained. For example, all sample names begin with the same two letters (EC), representing Erickson Creek, the study area in which the sample sites are located, and followed by two letters indicating the site name. Upland sites are designated either "LB" ("litterbag burned") or "LC" ("litterbag control”), where the term "litterbag” refers to a complementary study undertaken at these sites where decomposition rates were measured by litterbag techniques. Lowland sites are designated either "HB” ("Hess burned”) or "HC” (Hess control), where the term "Hess” refers to Hess Creek, which drains the watershed in which both lowland sites are located. Altogether, we designated four 
sample sites (ECLB, ECLC, ECHB, ECHC) to evaluate the effects of fire (burned versus unburned) and drainage (upland versus lowland).

\section{Soil Sampling}

In 2005, at each of the four sample sites (recently burned and unburned upland forest and peatland sites), we dug soilpits and described soil horizons, following U.S. Department of Agriculture's Natural Resource Conservation Service (USDA-NRCS) (Staff, 1998) and Canadian (Committee, 1998) methodologies. Samples of each organic-soil horizon type were collected by hand to preserve bulk density ( $n=5$ per site). In general, soil was excavated to the depth of mineral soil; however, we were unable to reach mineral soil at site ECHB, owing to a thick ( $>2 \mathrm{~m}$ ) layer of peat. Each soil horizon was labeled with two numbers representing the soil-profile number and basal depth of the sample (in centimeters). A decimal point separates the profile number from the basal depth; for example, ECHB 5.16 denotes a sample from the Erickson Creek Hess Creek burned site, profile 5, with a basal depth of $16 \mathrm{~cm}$.

Each sample was described according to USDA-NRCS (Staff, 1998) and Canadian (Committee, 1998) methodologies. We modified horizon codes according to the following scheme:

$\mathrm{L} \quad$ Live moss, which is green and generally contains some leaf and needle litter.

D Dead moss, which is composed of undecomposed or slightly-decomposed dead moss. This layer is characterized by fibric organic horizons that contain more moss than roots.

F Fibric (according to Canadian soil system) or fibrous organic layers, which vary in degree of decomposition but in which roots are more abundant than recognizable moss parts. Most of these layers would be considered Oi horizons (U.S. soil system) or upper duff (U.S. Forest Service [USFS] system).

M Mesic (according to Canadian soil system) organic layers, which are moderately decomposed, with few, if any, recognizable plant parts other than roots. These layers are generally considered Oe horizons (U.S. soil system) or lower duff layers (USFS system).

$\mathrm{H} \quad$ Humic (Canadian soil system) or sapric organic layers, which are highly decomposed. These layers generally smear upon squeezing and contain no recognizable plant parts. H layers are generally considered Oa horizons (U.S. soil system) or lower duff (USFS system).

A Mineral soil that forms at the surface or below organic-soil horizons (U.S. and Canadian soil systems), containing less than 20 volume percent organic matter, as judged in the field.

B Mineral soil that has formed below an A horizon (U.S. and Canadian soil systems), with little or none of its original lithologic structure.

C Mineral soil that has been little affected by pedogenic processes (U.S. and Canadian soil systems).

LT Litter layer (dead leaves, twigs, etc.)

LN Lichen

Horizon codes could be further described with a lowercase ' $b$ ' designating the horizon that had been burned, indicating anything from light scorching to deep charring. All soil profiles were subsampled by soil horizons. Subsamples were collected for bulk-density measurements, analytical purposes, and determination of moisture content. Samples were collected by either cutting out an area of known volume or using a core of known volume (Nadler and Wein, 1998). Samples were placed in clean Ziplock bags and shipped soon after collection to the USGS laboratory in Menlo Park, CA. 


\section{Soil-Sample Preparation and Drying}

Upon the arrival of samples at the USGS laboratory, samples were inventoried by using the field sheets. Any discrepancy between field descriptions and laboratory observations was resolved before sample preparation began. All samples were placed on open shelves in an isolated room and allowed to air-dry to a constant weight, as determined by weights measured at least one week apart. Temperature during air drying ranged from $20^{\circ} \mathrm{C}$ to $30^{\circ} \mathrm{C}$. After air drying, samples were oven-dried for 48 hours in a forced-draft oven. Samples that were classified as organic-soil horizons (e.g., moss, litter) were ovendried at $65^{\circ} \mathrm{C}$ to avoid loss or alteration of organic matter by oxidation or decomposition. The remaining samples were oven-dried at $105^{\circ} \mathrm{C}$.

After oven-drying, samples were thoroughly mixed, then split into subsamples for analysis and archiving. (Archive fractions of most of the samples described here are available by contacting J. Harden at the Menlo Park, CA, the U.S. Geological Survey). Samples were then processed in one of two ways, depending on horizon code. Mineral-soil samples were gently crushed by using a mortal and pestle, with care to break only aggregates, and then sieved through a 2-mm screen. Soil particles not passing the screen were removed, weighed, and saved separately; soil passing through the screen was then ground by using a mortar and pestle to pass through a 60 mesh $(0.246 \mathrm{~mm})$ screen. The ground material was mixed and placed in a labeled glass sample bottle for subsequent analyses. Organic samples were weighed, and roots wider than $1 \mathrm{~cm}$ in diameter were removed, weighed, and saved separately. The remaining sample was then milled in a Udy Corp. (Fort Collins, CO) Cyclone mill to pass through a $0.5-\mathrm{mm}$ screen. The milled sample was thoroughly mixed, and a representative sample placed in a labeled glass sample bottle for analytical chemistry.

\section{Soil Total Carbon and Nitrogen Measurements}

A Carlo Erba NA1500 elemental analyzer (EA) was used to determine total C and N contents of the soil samples. Because carbonates are generally absent in the study area and mineral-soil $\mathrm{pH}$ values were $\leq 7.0$ (Staff, 1951), all (or nearly all) soil C is considered organic. Samples were combusted in the presence of excess oxygen, and the resulting sample gasses were swept in a continuous flow of helium through an oxidation furnace, followed by a reduction furnace, to yield $\mathrm{CO}_{2}, \mathrm{~N}_{2}$, and water vapor. Water was removed by a chemical trap, and $\mathrm{CO}_{2}$ and $\mathrm{N}_{2}$ were chromatographically separated before the quantification of C and N (Pella, 1990a, b).

All samples were compared to a main working standard, ethylene diamine tetra-acetic acid (EDTA). the chemical formula for which corresponds to a $\mathrm{C}$ content of 41.09 weight percent and a $\mathrm{N}$ concentration of 9.59 weight percent. Additional working standards were analyzed as samples in all runs to check consistency and overall precision. Peach tree leaves (SRM-1547), issued by the National Institute of Standards and Technology (NIST), were included in runs composed of organic soil; and marine sediment (MESS-1), issued by the Chemistry Division of the Canadian National Research Council, was included in runs composed of mineral soils. Certified values for these standards were obtained from Becker (1990) and Govindaraju (1989), respectively.

\section{Vegetation Characterization}

The percentage cover of moss was quantified in 30- by 30-cm-square vegetation subplots $(n=10$ per site), using digital photographs and ESRI ArcMap and ArcCatalog software to digitize polygon boundaries of each dominant species and total moss cover, using the methods described in Harden and others (2009). In addition, understory vascular plants within each 30- by 30-cm plot were harvested, oven-dried at $65^{\circ} \mathrm{C}$, and then weighed for aboveground biomass estimates. 


\section{Environmental Measurements}

We measured the volumetric water content (VWC) of upper organic-soil horizons using an $\mathrm{ECH}_{2} \mathrm{O}$ Dialectric Aquameter (Decagon Devices, Inc., Pullman, WA). We measured the VWC of mineral-soil moisture by using a Hydrosense Water Content Meter (Decagon Devices, Inc., Pullman, WA). At all soil pits ( $n=10$ per site), $\mathrm{ECH}_{2} \mathrm{O}$ probes were inserted horizontally into the organic-soil layer at a depth of $10 \mathrm{~cm}$ below the moss surface in early May. Probes were not moved during the growing season, so that the organic-soil layer would not be disturbed. We measured VWC in the organic-soil horizon once a week, by connecting an $\mathrm{ECH}_{2} \mathrm{O}$ Checkmeter to the $\mathrm{ECH}_{2} \mathrm{O}$ probe and recording the readout (in millivolts). We measured VWC in mineral soil weekly by placing the Hydrosense probe vertically into the mineral soil. Measurements were made adjacent to $\mathrm{ECH}_{2} \mathrm{O}$ probes, and each measurement over the summer was made in approximately the same place. At the end of our study, we calibrated the $\mathrm{ECH}_{2} \mathrm{O}$ probes by harvesting a block of the organic-soil horizon encompassing each probe (approx 1,300- $\mathrm{cm}^{3}$ volume) and transporting each block to the laboratory. Organic-soil horizon blocks were saturated, allowed to drain to field capacity, and air dried at room temperature, while we weighed each organic horizon block and measured soil moisture content by using the $\mathrm{ECH}_{2} \mathrm{O}$ Checkmeter to generate a soil-moisture standard curve for each individual block from each plot. In general, we observed strong linear relations between measured organic-soil horizon VWC values and $\mathrm{ECH}_{2} \mathrm{O}$ readings (mean $R^{2}, 0.94$; range of $R^{2}$ values, $0.75-0.99$ ).

We also measured photosynthetically active radiation (PAR) using a handheld probe (Apogee Instruments, Inc., Logan, UT). Three replicate PAR measurements were taken at both the moss surface (ground PAR) and $2 \mathrm{~m}$ above each plot (subcanopy PAR) during the $\mathrm{CO}_{2}$ flux measurements. Thaw depth was measured every 7-10 days in conjunction with the $\mathrm{CO}_{2}$ flux measurements by inserting a stainless-steel depth probe into the soil and recording depth to ice. All environmental variables (soil temperature, soil moisture, PAR, thaw depth) were measured simultaneously with $\mathrm{CO}_{2}$ flux.

\section{$\mathrm{CO}_{2}$ Flux Measurements}

We measured $\mathrm{CO}_{2}$ flux at the soil-atmosphere interface every 7-10 days from mid-May to midSeptember 2005 at each of the four sample sites. Five permanent plexiglass collars (30 by $30 \mathrm{~cm}$ ) were installed at random within each site and inserted about $3 \mathrm{~cm}$ into the moss layer. Net ecosystem exchange (NEE) and ecosystem respiration (ER) were measured by using an LI-840 infrared gas analyzer (Licor Inc., Lincoln, NE) and a clear plexiglass chamber (26 by 26 by $26 \mathrm{~cm}$ ). $\mathrm{CO}_{2}$ flux was measured under ambient light conditions for NEE and under dark conditions for ER, using a two-layer cloth shroud with a reflective surface to exclude solar radiation for ecosystem respiration. For both $\mathrm{NEE}$ and ER measurements, $\mathrm{CO}_{2}$ concentrations inside the chamber headspaces were logged every second for a measurement period of about $90 \mathrm{~s}$. $\mathrm{CO}_{2}$ flux rates were calculated as the linear regression between $\mathrm{CO}_{2}$ concentrations at 15 and $70 \mathrm{~s}$ time. The average chamber volume was estimated by injecting $2 \mathrm{~mL}$ of pure $\mathrm{CO}_{2}$ into the chamber headspace (closed from atmosphere) and recording the increase in $\mathrm{CO}_{2}$ concentration after $90 \mathrm{~s}$ of diffusive mixing.

\section{Data-set descriptions}

Separate downloadable files contain the soil data collected from the sample sites described in this report. Appendix 2 describes in detail the data within the following eight spreadsheet files (1) Erickson_Flux_Soil_Field, which contains field descriptions, such as root abundance, color, and soil texture, of the sampled soils; (2) Erickson_Flux_Soil_Physical, which contains physical descriptions of the samples, such as VWC and bulk density; (3) Erickson Flux_Soil_Chemistry, which contains 
elemental C, elemental N, and loss-on-ignition (LOI) values; (4) Erickson_Flux_Soil_Transects, which contains qualitative descriptions of soils from plots where no soils were actually sampled; (5)

Erickson_Flux_MossCover, which contains percentage-of-cover data for various moss species at each study plot; (6) Erickson_Flux_VascularBiomass, which contains biomass data for forest-floor vascular plants from each study plot; (7) Erickson_Flux_Handheld, which contains data from field measurements made in association with $\mathrm{CO}_{2}$ flux measurements, including VWC, PAR and thaw depth; and (8) Erickson_Flux_CO2, which contains $\mathrm{CO}_{2}$ flux data. Soil temperature was also measured at each study plot; these data are posted on the Bonanza Creek Long-Term Ecological Research's Web site (http://www.lter.uaf.edu/).

\section{Acknowledgments}

We thank Lee Pruett and Jamie Hollingsworth for their assistance in the field. This research was funded by the USGS, the Bonanza Creek Long-Term Ecological Research (LTER) program (funded jointly by National Science Foundationa [NSF] grant DEB-0423442 and USFS, Pacific Northwest Research Station grant PNW01-JV11261952-231).

\section{References Cited}

Becker, D.A., 1990, Homogeneity and evaluation of the new NIST leaf certified reference materials, in Nuclear analytical methods in the life sciences: Gaithersburg, MD, National Institute of Standards, p. 571-577.

Committee, C.A.S.C., 1998, The Canadian system of soil classification. Ontario (Canada): NRC Canada Research Press, 187 p.

Damman, A.W.H., and French, T.W., 1987, The ecology of peat bogs of the glaciated northeastern Unisted States; a community profile: U.S. Fish and Wildlife Service, Biological Report, 85(7.16), $100 \mathrm{p}$.

Govindaraju, K., 1989, Compilation of working value and sample description for 272 geostandards: Geostandards Newsletter, v. 13, p. 1-113.

Harden, J.W., Trumbore, S.E., Stocks, B.J., Hirsch, A., Gower, S.T., O’Neill, K.P., and Kasischke, E.S., 2000, The role of fire in the boreal carbon budget: Global Change Biology, v. 6, supp. 1, p. 174184.

Harden, J.W., Munster, J., Manies, K.L., Mack, M.C., and Bubier, J.L., 2009, Changes in species, areal cover, and production of moss across a fire chronosequence in interior Alaska: U.S. Geological Survey Open-File Report 2009-1208, 22 p. [http://pubs.usgs.gov/of/2009/1208/].

Kane, E.S., Kasischke, E.S., Valentine, D.W., Turetsky, M.R., and McGuire, A.D., 2007, Topographic influences on wildfire consumption of soil organic carbon in interior Alaska: implications for black carbon accumulation: Journal of Geophysical Research, v. 112, G03017, doi:10.1029/2007JG000458.

Kasischke, E.S., French, N.H.F., Borgeau-Chavez, L.L., and Christensen, N.L. Jr, 1995, Estimating release of carbon from 1990 and 1991 forest fires in Alaska: Journal of Geophysical Research, v. 100, p. 2941-2951.

Kasischke, E.S., O’Neill, K.P., French, N.H.F., and Borgeau-Chavez, L.L., 2000, Controls on patterns of biomass burning in Alaskan boreal forests, in Kasischke, E.S., Stocks, B.J., eds., Fire, climate change, and carbon cycling in the North American boreal forest: New York. Springer, p. 148-163.

Kasischke, E.S., and Turetsky, M.R., 2006, Recent changes in the fire regime across the North American boreal region: Geophysical Research Letters, v. 33, doi:10.1029/2006GL025677. 
Manies, K.L., Harden, J.W., Silva, S.R., Briggs, P.H., and Schmid, B.M., 2004, Soil data from Picea mariana stands near Delta Junction, Alaska of different ages and soil drainage types: U.S. Geological Survey Open-File Report 2004-1271, 19 p. [http://pubs.usgs.gov/of/2004/1271/].

Nadler, I.A., and Wein, R.W., 1998, A new forest floor corer for rapid sampling, minimal disturbance and adequate precision: Silva Fennica, v. 32, no. 4, p. 373-381.

O’Donnell, J.A., Turetsky, M.R., Harden, J.W., Manies, K.L., Pruett, L.E., Shetler, G., and Neff, J.C., 2009, Interactive effects of fire, soil climate, and moss on $\mathrm{CO}_{2}$ fluxes in black spruce ecosystems of interior Alaska: Ecosystems, v. 12, p. 57-72.

O'Neill, K.P., Kasischke, E.S., and Richter, D.D., 2002, Environmental controls on soil $\mathrm{CO}_{2}$ flux following fire in black spruce, white spruce, and aspen stand of interior Alaska: Canadian Journal of Forest Research, v. 32, p. 1525-1541.

O'Neill, K.P., Kasischke, E.S., and Richter, D.D., 2003, Seasonal and decadal patterns of soil carbon uptake and emission along an age-sequence of burned black spruce stands in interior Alaska: Journal of Geophysical Research, v. 108, no. D1, p. doi:10.1029/2001JD000443.

Pella, E., 1990a, Elemental organic analysis. Part 1, Historical developments: American Laboratory, v. 22, no. 2, p. 116-125.

Pella, E., 1990b, Elemental organic analyzer. Part 2, State of the art: American Laboratory, v. 22, no. 12, p. 28-32.

Richter, D.D., O’Neill, K.P., and Kasischke, E.S., 2000, Stimulation of soil respiration in burned black spruce (Picea mariana L.) forest ecosystems; a hypothesis, in Kasischke, E.S., Stocks, B.J., eds., Fire, climate change, and carbon cycling in the North American boreal forest: New York, Springer, p. 164-178.

Staff, S.S., 1998, Keys to soil taxonomy ( $8^{\text {th }}$ ed.): Blacksburg, Va., Pocahontas Press, 599 p. 


\section{Appendix 1: Sample-Site Descriptions}

This appendix describes the locations of each site sampled by the USGS for the Erickson Creek $\mathrm{CO}_{2}$ Flux project. The sample sites are located north of Livengood, Alaska, along the Dalton Highway. The following text gives general directions to each of our sites and assumes that the direction of travel is north from Livengood on the Dalton Highway toward the Yukon River Bridge.

We sampled soils at a total of four sites: upland burn (ECLB), upland control (ECLC), lowland burn (ECHB), and lowland control (ECHC). Within each site, we sampled 10 plots arranged in a broad circle; the boundaries of each circle were typically marked with pink/black flagging. During our study, a guidewire made of string was set up around the circle to ensure that researchers would not trample the plots during repeat visits. Along each circular transect, a total of 10 30- by $30-\mathrm{cm}$ plots were established approximately $5 \mathrm{~m}$ apart. Temperature and moistures probes were positioned at all plots, whereas gas-flux collars were installed at only 5 of the 10 plots. Directions and global positioning system (GPS) coordinates are provided for each sample site, but not each plot; including plots where soil was sampled and (or) only described.

\section{ECLB (Upland Burned)}

Park at the pulloff on the left side of the road right before the Erickson Creek Bridge (mile 12 of the Dalton Highway). Continue by walking north, up the hill, until pink/black flagging marking the trailhead is visible about halfway up on the left side of the road. The path to the sample site is also marked with pink/black flagging placed every 10 to $20 \mathrm{~m}$ on standing dead black spruce trees. The plots are located at coordinates lat $65.57626^{\circ} \mathrm{N}$., long $148.95951^{\circ} \mathrm{W}$. (NAD83). Plots are located every $5 \mathrm{~m}$ along a circular transect in recently burned black spruce forest with lots of standing dead trees and burned dead moss and fibrous organic matter on the forest floor.

- ECLC 15 - Described on September 15, 2005, by Kristen Manies. Instrumented plot.

- ECLC 16 - Described on September 15, 2005, by Kristen Manies. Instrumented plot.

- ECLC 17 - Described on September 15, 2005, by Kristen Manies. Instrumented plot.

- ECLC 18 - Described on September 15, 2005, by Kristen Manies. Instrumented plot.

- ECLC 19 - Described on September 15, 2005, by Kristen Manies. Instrumented plot.

- ECLB 20 - Sampled on September 15, 2005, by Kristen Manies. Flux-collar plot.

- ECLB 21 - Sampled on September 14, 2005, by Kristen Manies. Flux-collar plot.

- ECLB 22 - Sampled on September 15, 2005, by Kristen Manies. Flux-collar plot.

- ECLB 23 - Sampled on September 15, 2005, by Kristen Manies. Flux-collar plot.

- ECLB 24 - Sampled on September 15, 2005, by Kristen Manies. Flux-collar plot.

\section{ECLC (Upland Control)}

Park at the pulloff on the left side of the road right before the Erickson Creek Bridge (mile 12 of the Dalton Highway). Continuing by walking north, up the hill, which makes an S-shaped turn. At the top of the hill, follow the road as it makes a sharp left turn. Continue walking until you see a large tire on the left side of the road. Turn left into the woods and begin searching for pink/black flagging, which marks a short trail to the sample site. The plots are located at lat $65.577626^{\circ} \mathrm{N}$., long $148.95982^{\circ}$ 
W. Plots are located every $5 \mathrm{~m}$ in an oval pattern. All plots are located in a mature black spruce forest with Hylcomium sp. and Pleurozium sp.

- ECLC 10 - Sampled on September 15, 2005, by Kristen Manies. Flux-collar plot.

- ECLC 11 - Sampled on September 15, 2005, by Kristen Manies. Flux-collar plot.

- ECLC 12 - Sampled on September 15, 2005, by Kristen Manies. Flux-collar plot.

- $\quad$ ECLC 13 - Sampled on September 13, 2005, by Kristen Manies. Flux-collar plot.

- $\quad$ ECLC 14 - Sampled on September 13, 2005, by Kristen Manies. Flux-collar plot.

- $\quad$ ECLC 15 - Described on September 13, 2005, by Kristen Manies. Instrumented plot.

- ECLC 16 - Described on September 13, 2005, by Kristen Manies. Instrumented plot.

- ECLC 17 - Described on September 13, 2005, by Kristen Manies. Instrumented plot.

- $\quad$ ECLC 18 - Described on September 13, 2005, by Kristen Manies. Instrumented plot.

- $\quad$ ECLC 19 - Described on September 13, 2005, by Kristen Manies. Instrumented plot.

\section{ECHB (Lowland Burned)}

From Erickson Creek, drive north 10 mi to Hess Creek. Just south of the Hess Creek Bridge, turn right onto a dirt road maintained by Alyeska Pipeline, Inc. Park on the left side of the dirt road before the Alyeska gate. Walk around the gate and continue east on the dirt road for $\sim 250 \mathrm{~m}$. On the left side of the road is some pink/black flagging that signifies the path to the sample site. Follow the pink/black flagging $400 \mathrm{~m}$ downhill. Find the site at the base of the toeslope after passing a 10-m-wide winter trail. Site coordinates are lat $65.667269^{\circ} \mathrm{N}$., long $148.967820^{\circ} \mathrm{W}$. Plots are located every $5 \mathrm{~m}$ in a loose circle among recently burned black spruce stands characterized by sparse standing dead trees and burned Sphagnum sp. peat.

- ECHB 1 - Described on September 14, 2005, by Kristen Manies. Instrumented plot.

- ECHB 2 - Described on September 14, 2005, by Kristen Manies. Instrumented plot

- $\quad$ ECHB 3 - Described on September 14, 2005, by Kristen Manies. Instrumented plot.

- ECHB 4 - Described on September 14, 2005, by Kristen Manies. Instrumented plot.

- $\quad$ ECHB 5 - Described on September 14, 2005, by Kristen Manies. Instrumented plot.

- ECHB 16 - Sampled on April 5, 2006, by Kristen Manies. Flux-collar plot.

- $\quad$ ECHB 17 - Sampled on April 5, 2006, by Kristen Manies. Flux-collar plot.

- ECHB 18 - Sampled on April 5, 2006, by Kristen Manies. Flux-collar plot.

- ECHB 19 - Sampled on April 5, 2006, by Kristen Manies. Flux-collar plot.

- $\quad$ ECHB 20 - Sampled on May 10, 2006, by Jon O’Donnell. Flux-collar plot.

\section{ECHC (Lowland Control)}

From Erickson Creek, drive north 10 mi to Hess Creek. Just south of the Hess Creek bridge, turn right onto a dirt road maintained by Alyeska Pipeline, Inc. Park on the left side of the dirt road before the Alyeska gate. Walk around the gate and continue east on the dirt road for $\sim 250 \mathrm{~m}$. On the 
left side of the road is some pink/black flagging that signifies the path to the sample site. Follow the pink/black flagging $400 \mathrm{~m}$ downhill. Find the study site at the base of the toeslope after passing a 10-mwide winter trail. The control is easily identified as the only unburned island in a sea of burned black spruce. The plot is located at lat $65.667269^{\circ} \mathrm{N}$., long $148.967820^{\circ} \mathrm{W}$. Plots are located every $5 \mathrm{~m}$ in a loose circle in a mature lowland black spruce stand with large Sphagnum sp. hummocks.

- $\quad$ ECHC 1 - Sampled on September 16, 2005, by Kristen Manies. Flux-collar plot.

- ECHC 2 - Sampled on September 16, 2005, by Kristen Manies. Flux-collar plot.

- $\quad$ ECHC 3 - Sampled on September 16, 2005, by Kristen Manies. Flux-collar plot.

- $\quad$ ECHC 4 - Sampled on September 16, 2005, by Kristen Manies. Flux-collar plot.

- $\quad$ ECHC 5- Sampled on September 16, 2005, by Kristen Manies. Flux-collar plot.

- ECHC 11 - Sampled on April 5, 2006, by Jonathan O’Donnell and Kristen Manies. Flux-collar plot.

- ECHC 12 - Sampled on April 6, 2006, by Jonathan O’Donnell and Kristen Manies. Flux-collar plot.

- ECHC 13 - Sampled on April 6, 2006, by Jonathan O’Donnell and Kristen Manies. Flux-collar plot. 


\section{Appendix 2: General Description of Data Files}

The following sections briefly describe the contents of eight downloadable spreadsheet files containing the soil data collected from sites near Erickson Creek, Alaska. Unavailable or inapplicable data are indicated by a dash (“-“). Additional information on these sample sites, as well as sampling and analyses procedures is presented above in the main.

\section{Erickson_Flux_Soil_Field}

This file contains the field descriptions of the sampled soils. Column descriptions are as follows.

\begin{tabular}{|l|l|}
\hline Sample ID & $\begin{array}{l}\text { Sample identification: The first two letters in the sample labels represent the } \\
\text { study area, Erickson Creek (EC); The third letter represents the specific } \\
\text { sample site within the study are (L, litterbag; H, Hess Creek); and the fourth } \\
\text { letter represents the burn status of the site (B, burned; C, control or unburned). } \\
\text { The number that follows these four characters indicates the plot. A decimal } \\
\text { point separates the profile number from the basal depth of the sample (in } \\
\text { centimeters). }\end{array}$ \\
\hline Bepth & $\begin{array}{l}\text { Borizon type of the sample, as defined in the field: L, live moss; D, dead } \\
\text { moss; F, fibric organic matter (OM); M, mesic OM; H, humic OM; A, A } \\
\text { mineral-soil horizon; LI, lichen; LT, litter; WD, wood. A lowercase "b" } \\
\text { before a horizon code indicates that the sample showed evidence of burning } \\
\text { (e.g., scorched, charred). }\end{array}$ \\
\hline $\begin{array}{l}\text { Code } \\
\text { Sample description of the sample. } \\
\text { Description }\end{array}$ & $\begin{array}{l}\text { Root abundance and size, using conventions of the U.S. Department of } \\
\text { Agricultures's Agricultural Research Service (USDA-ARS) (Staff, 1998). }\end{array}$ \\
\hline Roots & $\begin{array}{l}\text { If an organic soil, the classification according to the von Post scale of } \\
\text { humification (Damman and French, 1987); if a mineral soil, the soil-texture } \\
\text { class as described in the field, using the conventions of USDA-ARS (Staff, } \\
\text { 1998). }\end{array}$ \\
\hline $\begin{array}{l}\text { Von Post or } \\
\text { Texture }\end{array}$ & $\begin{array}{l}\text { Height of each basal depth above the mineral-soil boundary. Therefore, the } \\
\text { bottom organic layer is zero, and all mineral horizons are negative numbers. }\end{array}$ \\
\hline $\begin{array}{l}\text { Height above mineral soil as measured in the laboratory. Deionized water was added } \\
\text { mineral }\end{array}$ & $\begin{array}{l}\text { to create a soil slurry (50/50 soil/water) before measurement. } \\
\text { pH }\end{array}$ \\
\hline
\end{tabular}




\section{Erickson_Flux_Soil_Transects}

This file contains field descriptions of the soils at sample sites that were described but not sampled. Column descriptions are as follows:

\begin{tabular}{|l|l|}
\hline Sample ID & $\begin{array}{l}\text { Sample identification: The first two letters in the sample labels represent the } \\
\text { study area, Erickson Creek (EC); The third letter represents the specific } \\
\text { sample site within the study are (L, litterbag; H, Hess Creek); and the fourth } \\
\text { letter represents the burn status of the site (B, burned; C, control or unburned). } \\
\text { The number that follows these four characters indicates the plot. A decimal } \\
\text { point separates the profile number from the basal depth of the sample (in } \\
\text { centimeters). }\end{array}$ \\
\hline $\begin{array}{l}\text { Depth } \\
\text { Code Horizon }\end{array}$ & $\begin{array}{l}\text { Horizon type of the sample, as defined in the field: L, live moss; D, dead } \\
\text { moss; F, fibric organic matter (OM); M, mesic OM; H, humic OM; A, A } \\
\text { mineral-soil horizon; LI, lichen; LT, litter; WD, wood. A lowercase "b" } \\
\text { before a horizon code indicates that the sample showed evidence of burning } \\
\text { (e.g., scorched, charred). }\end{array}$ \\
\hline $\begin{array}{l}\text { Brief description of the sample. } \\
\text { Sample } \\
\text { Description }\end{array}$ & $\begin{array}{l}\text { Where, by whom, and when the description was made, as well as the } \\
\text { dominant tree and moss species. Depth to frozen layers, as determined by } \\
\text { probing, is also noted if measured. }\end{array}$ \\
\hline Plot Information Class & $\begin{array}{l}\text { Root abundance and size, using conventions of the USDA-NRCS (Staff } \\
\text { 1998). } \\
\text { If an organic soil, the classification according to the von Post scale of } \\
\text { humification (Damman and French, 1987); if a mineral soil, the soil texture } \\
\text { class, using the conventions of the USDA-NRCS (Staff, 1998). }\end{array}$ \\
\hline Height of soil horizon above organic- mineral-soil interface (in centimeters). \\
\hline Roots
\end{tabular}




\section{Erickson_Flux_Soil_Physical}

This file contains physical data, such as bulk density, volumetric moisture content, and particle-size analysis. Column definitions are as follows:

\begin{tabular}{|c|c|}
\hline Sample ID & $\begin{array}{l}\text { Sample identification: The first two letters in the sample labels represent the } \\
\text { study area, Erickson Creek (EC); The third letter represents the specific sample } \\
\text { site within the study are (L, litterbag; H, Hess Creek); and the fourth letter } \\
\text { represents the burn status of the site (B, burned; C, control or unburned). The } \\
\text { number that follows these four characters indicates the plot. A decimal point } \\
\text { separates the profile number from the basal depth of the sample (in } \\
\text { centimeters). }\end{array}$ \\
\hline Basal Depth & Basal depth (in centimeters) of sampling increment. \\
\hline $\begin{array}{l}\text { Field Horizon } \\
\text { Code }\end{array}$ & $\begin{array}{l}\text { Horizon type of the sample, as defined in the field: L, live moss; D, dead moss; } \\
\text { F, fibric organic matter (OM); M, mesic OM; H, humic OM; A, A mineral-soil } \\
\text { horizon; LI, lichen; LT, litter; WD, wood. A lowercase "b” before a horizon } \\
\text { code indicates that the sample showed evidence of burning (e.g., scorched, } \\
\text { charred). }\end{array}$ \\
\hline $\begin{array}{l}\text { Sample } \\
\text { Description }\end{array}$ & Brief description of the sample. \\
\hline Date Sampled & Date when sample was obtained (month/day/year). \\
\hline Thickness & Thickness of soil horizon. \\
\hline $\begin{array}{l}>2 \mathrm{~mm} \text { in } \\
\text { Sample }\end{array}$ & $\begin{array}{l}\text { Dry-weight percentage of soil particles not passing through a 2-mm sieve after } \\
\text { gentle crushing. }\end{array}$ \\
\hline $\begin{array}{l}>1 \mathrm{~cm} \text { in } \\
\text { Sample }\end{array}$ & Dry-weight percentage of roots wider than $1 \mathrm{~cm}$ in diameter in the sample. \\
\hline $\begin{array}{l}\text { Bulk Density } \\
(<2 \mathrm{~mm})\end{array}$ & $\begin{array}{l}\text { Grams of ovendried soil per cubic centimeter, with soil particles larger than } 2 \\
\text { mm and roots wider than } 1 \mathrm{~cm} \text { in diameter removed. }\end{array}$ \\
\hline Bulk Density & $\begin{array}{l}\text { Grams of ovendried soil per cubic centimeter for the entire soil sample, with no } \\
\text { fractions excluded. Calculated similarly to bulk bensity }(<2 \mathrm{~mm}) \text { except the } \\
\text { weight of particles larger than } 2 \mathrm{~mm} \text { and roots wider than } 1 \mathrm{~cm} \text { in diameter have } \\
\text { been included. }\end{array}$ \\
\hline $\begin{array}{l}\text { Volumetric } \\
\text { Field Moisture }\end{array}$ & Volume percentage of water in the sample. \\
\hline $\begin{array}{l}\text { Moisture in } \\
\text { Air-dry Sample }\end{array}$ & $\begin{array}{l}\text { Weight percentage, of moisture remaining in a sample after air drying to } \\
\text { constant weight as determined by subsequently oven-drying the sample. }\end{array}$ \\
\hline
\end{tabular}




\section{Erickson_Flux_Soil_Chemistry}

This file contains chemical data obtained from an elemental analyzer/mass spectrometer (EA/IRMS). Column definitions are as follows:

\begin{tabular}{|c|c|}
\hline Sample ID & $\begin{array}{l}\text { Sample identification: The first two letters in the sample labels represent } \\
\text { the study area, Erickson Creek (EC); The third letter represents the specific } \\
\text { sample site within the study are (L, litterbag; H, Hess Creek); and the } \\
\text { fourth letter represents the burn status of the site (B, burned; C, control or } \\
\text { unburned). The number that follows these four characters indicates the } \\
\text { plot. A decimal point separates the profile number from the basal depth of } \\
\text { the sample (in centimeters). }\end{array}$ \\
\hline Basal Depth & Basal depth (in centimeters) of sampling increment. \\
\hline $\begin{array}{l}\text { Field Horizon } \\
\text { Code }\end{array}$ & $\begin{array}{l}\text { Horizon type of the sample, as defined in the field: L, live moss; D, dead } \\
\text { moss; F, fibric organic matter (OM); M, mesic OM; H, humic OM; A, A } \\
\text { mineral-soil horizon; LI, lichen; LT, litter; WD, wood. A lowercase "b" } \\
\text { before a horizon code indicates that the sample showed evidence of } \\
\text { burning (e.g., scorched, charred). }\end{array}$ \\
\hline $\begin{array}{l}\text { Sample } \\
\text { Description }\end{array}$ & Brief description of the sample. \\
\hline$\% \mathrm{C}$ & $\begin{array}{l}\text { Weight percentage of carbon in an ovendried soil sample with material >2 } \\
\mathrm{mm} \text { or } 1 \mathrm{~cm} \text { in diameter removed. }\end{array}$ \\
\hline$\% \mathrm{~N}$ & $\begin{array}{l}\text { Weight percentage of nitrogen in an ovendried soil sample with material } \\
>2 \mathrm{~mm} \text { or } 1 \mathrm{~cm} \text { in diameter removed. }\end{array}$ \\
\hline$\delta^{13} \mathrm{C}$ & $\begin{array}{l}\text { Stable isotope signature of ovendried sample with material }>2 \mathrm{~mm} \text { or } 1 \mathrm{~cm} \\
\text { in diameter removed. }\end{array}$ \\
\hline
\end{tabular}

\section{Erickson_Flux_MossCover}

\begin{tabular}{|l|l|}
\hline Site ID & $\begin{array}{l}\text { Sample identification: The first two letters in the sample labels represent the } \\
\text { study area, Erickson Creek (EC); The third letter represents the specific } \\
\text { sample site within the study are (L, litterbag; H, Hess Creek); and the fourth } \\
\text { letter represents the burn status of the site (B, burned; C, control or } \\
\text { unburned). The number that follows these four characters indicates the plot. }\end{array}$ \\
\hline Other Plot Name & Alternative site ID used to describe the plot in the field. \\
\hline $\begin{array}{l}\text { Aulacomnium } \\
\text { palustre }\end{array}$ & Percentage cover of the moss Aulacomnium palustre. \\
\hline $\begin{array}{l}\text { Ceratodon } \\
\text { purpureus }\end{array}$ & Percentage cover of the moss Ceratodon purpureus. \\
\hline $\begin{array}{l}\text { Dicranum } \\
\text { polysetum }\end{array}$ & Percentage cover of the moss Dicranum polysetum. \\
\hline $\begin{array}{l}\text { Hylocomium } \\
\text { splendens }\end{array}$ & Percentage cover of the moss Hylocomium splendens. \\
\hline $\begin{array}{l}\text { Pleurozium } \\
\text { schreberi }\end{array}$ & Percentage cover of the moss Pleurosium schreberi. \\
\hline $\begin{array}{l}\text { Tomenthypnum } \\
\text { nitens }\end{array}$ & Percentage cover of the moss Tomenthypnum nitens. \\
\hline
\end{tabular}




\begin{tabular}{|l|l|}
\hline Sphagnum fuscum & Percentage cover of the moss Sphagnum fuscum. \\
\hline Litter & Percentage cover characterized as leaf or plant litter. \\
\hline Lichen & Percentage cover of lichen. \\
\hline Bare/Wood & Percentage cover characterized as bare or as wood. \\
\hline
\end{tabular}

\section{Erickson_Flux_VascularBiomass}

\begin{tabular}{|c|c|}
\hline Site ID & $\begin{array}{l}\text { Sample identification: The first two letters in the sample labels represent the } \\
\text { study area, Erickson Creek (EC); The third letter represents the specific } \\
\text { sample site within the study are (L, litterbag; H, Hess Creek); and the fourth } \\
\text { letter represents the burn status of the site (B, burned; C, control or } \\
\text { unburned). The number that follows these four characters indicates the plot. }\end{array}$ \\
\hline Other Plot $\mathrm{N}$ & Alternative site ID used to describe the plot in the field. \\
\hline & the vascular plant beir \\
\hline iom? & for each species type at each plot. \\
\hline
\end{tabular}

\section{Erickson_Flux_Handheld}

This file contains miscellaneous field data that was collected manually every 7-10 days. Specifically, we measured thaw depth in three localities near each plot. We also measured PAR three times at chest level (2 m PAR) and at three points directly above the ground surface (ground PAR). Additionally, we measured organic- and mineral-soil moisture content at one place in each plot.

\begin{tabular}{|l|l|}
\hline Date & Date when each measurement was taken in the field. \\
\hline Site ID & $\begin{array}{l}\text { Sample identification: The first two letters in the sample labels represent the } \\
\text { study area, Erickson Creek (EC); The third letter represents the specific sample } \\
\text { site within the study are (L, litterbag; H, Hess Creek); and the fourth letter } \\
\text { represents the burn status of the site (B, burned; C, control or unburned). The } \\
\text { number that follows these four characters indicates the plot. }\end{array}$ \\
\hline $\begin{array}{l}\text { Other Plot } \\
\text { Name }\end{array}$ & Alternative site ID used to describe the plot in the field. \\
\hline $\begin{array}{l}\text { Thaw Depth } \\
\text { Rep 1 }\end{array}$ & Depth of thaw (in centimeters) within the soil active layer. \\
\hline $\begin{array}{l}\text { Thaw Depth } \\
\text { Rep 2 }\end{array}$ & Depth of thaw (in centimeters) within the soil active layer. \\
\hline $\begin{array}{l}\text { Thaw Depth } \\
\text { Rep 3 }\end{array}$ & Depth of thaw (in centimeters) within the soil active layer. \\
\hline Organic VWC & Volumetric water content of the soil organic layer. \\
\hline Mineral VWC & Volumetric water content of the soil mineral layer (Fr, frozen; Sat, saturated). \\
\hline $\begin{array}{l}\text { 2m PAR } \\
\text { Rep 1 }\end{array}$ & PAR value measured at chest height. \\
\hline $\begin{array}{l}\text { 2m PAR } \\
\text { Rep 2 }\end{array}$ & PAR value measured at chest height. \\
\hline $\begin{array}{l}\text { 2m PAR } \\
\text { Rep 3 }\end{array}$ & PAR value measured at chest height. \\
\hline Ground PAR & PAR value measured just above the ground surface. \\
\hline
\end{tabular}




\begin{tabular}{|l|l|}
\hline Rep 1 & \\
\hline $\begin{array}{l}\text { Ground PAR } \\
\text { Rep 1 }\end{array}$ & PAR value measured just above the ground surface. \\
\hline $\begin{array}{l}\text { Ground PAR } \\
\text { Rep 1 }\end{array}$ & PAR value measured just above the ground surface. \\
\hline
\end{tabular}

\section{Erickson_Flux_CO2}

This file contains data for the $\mathrm{CO}_{2}$ flux measured at each plot every 7-10 days during the 2005 growing season. Fluxes were measured by using a LI-840 infrared gas analyzer (Licor Inc., Lincoln, $\mathrm{NE}$ ). For NEE, we measured $\mathrm{CO}_{2}$ fluxes under ambient light conditions; for $\mathrm{ER}, \mathrm{CO}_{2}$ flux was measured in the dark by using a two-layer cloth shroud with a reflective surface to exclude solar radiation.

\begin{tabular}{|l|l|}
\hline Date & Date when each measurement was taken in the field. \\
\hline Site ID & $\begin{array}{l}\text { Sample identification: The first two letters in the sample labels represent the } \\
\text { study area, Erickson Creek (EC); The third letter represents the specific sample } \\
\text { site within the study are (L, litterbag; H, Hess Creek); and the fourth letter } \\
\text { represents the burn status of the site (B, burned; C, control or unburned). The } \\
\text { number that follows these four characters indicates the plot. }\end{array}$ \\
\hline $\begin{array}{l}\text { Other Plot } \\
\text { Name }\end{array}$ & \begin{tabular}{l} 
Alternative site ID used to describe the plot in the field. \\
\hline NEE
\end{tabular} \\
\hline ER & $\begin{array}{l}\text { Net ecosystem exchange (grams carbon per square meter per day) measured } \\
\text { under ambient light conditions. }\end{array}$ \\
\hline & $\begin{array}{l}\text { Ecosystem respiration (grams carbon per square meter per day) measured in the } \\
\text { dark. }\end{array}$ \\
\hline
\end{tabular}

